\title{
Rancang Bangun Alat Pengukur Suhu Tubuh Pintar Berbasis Internet Of Things
}

\author{
Arif Rahman Halim ${ }^{1 *}$, Muhammad Saiful2 ${ }^{2}$, L. Kertawijaya ${ }^{3}$ \\ 1,3Program Studi Teknik Informatika, Universitas Hamzanwadi \\ 2Program Studi Sistem Informasi, Universitas Hamzanwadi \\ *arifrahmanhalim1@gmail.com
}

\begin{abstract}
Abstrak
Pengukuran suhu tubuh bisa menjadi dasar untuk menentukan kesehatan seseorang. Meningkatnya suhu tubuh juga bisa menjadi acuan untuk mengetahui apakah seseorang mengalami gejala awal suatu penyakit menular seperti Covid 19 yang saat ini menjadi pandemi atau hanya demam biasa, pengukuran suhu tubuh awalnya di lakukan secara manual menggunakan alat thermogun dan penggunaan alat thermogun mengharuskan seseorang berdekatan secara langsung yang akan membuat resiko tertular penyakit semakin tinggi. penelitian ini membuat alat pengukur suhu tubuh pintar berbasis intrernet of things, internet of things adalah sebuah konsep yang bertujuan untuk memperluas manfaat dari konektivitas internet yang tersambung secara terus-menerus seperti kemampuan berbagi data, remote control, dan sebagainya, sehingga diharapkan dengan penggunaan teknologi internet of things alat pengukur suhu tubuh pintar ini bisa di kontrol dari jarak jauh yang tidak terbatasi oleh jarak dan waktu selama sistem terhubung dengan jaringan internet. Sistem menggukan sensor ultrasonik untuk mendeteksi seseorang dan sensor MLX-90614 untuk pengukuran suhu tubuh non-kontak untuk mendeteksi suhu tubuh, setelah itu data akan di olah oleh nodemcu. Data tersebut lalu ditampilkan melalui aplikasi blynk yang sudah terhubung secara realtime dan data yang sudah diolah oleh esp8266 juga ditampilkan menggunakan LCD OLED dan selain itu juga output yang dihasilkan dalam bentuk suara sebagai pemberitahuan menggunakan DFPlayer mini Mp3.
\end{abstract}

Kata kunci: Suhu tubuh, NodeMcu, Internet Of Things, aplikasi blynk.

\begin{abstract}
Measurement of body temperature can be the basis for determining a person's health. The increase in body temperature can also be a reference to find out whether a person is experiencing early symptoms of an infectious disease such as Covid 19 which is currently a pandemic or just a common fever. Body temperature measurements were initially carried out manually using a thermogun and the use of a thermogun requires a person to be in direct proximity. which will increase the risk of contracting the disease. this research makes a smart body temperature measuring device based on the internet of things, internet of things is a concept that aims to expand the benefits of continuously connected internet connectivity such as the ability to share data, remote control, and so on, so it is hoped that with the use of internet technology of things this smart body temperature measuring device can be controlled remotely which is not limited by distance and time as long as the system is connected to the internet network. The system uses an ultrasonic sensor to detect a person and the MLX-90614 sensor for non-contact body temperature measurement to detect body temperature, after which the data will be processed by nodemcu. The data is then displayed through the blynk application which is connected in real time and the data that has been processed by esp8266 is also displayed using an OLED LCD and besides that, the output is in the form of sound as a notification using DFPlayer mini Mp3.
\end{abstract}

Keywords: Body temperature, NodeMcu, Internet Of Things, blynk application. 


\section{Pendahuluan}

Pandemi Kesehatan merupakan suatu hal yang terpenting dalam kehidupan manusia pada saat ini, baik itu kesehatan badan, jiwa dan sosial. Kesehatan merupakan suatu elemen yang sangat vital dalam melakukan segala aktivitas yang dilakukan oleh manusia. Pengukuran tanda-tanda vital atau tanda-tanda seseorang dalam keadaan sehat tersebut akan memberikan informasi yang berharga terutama mengenai kesehatan manusia secara umum. Dalam pengukuran suhu tubuh merupakan salah satu hal yang paling mendasar untuk mengetahui tanda klinis dan berguna untuk mendiagnosis suatu penyakit, karena pada masa pandemi Covid-19 saat ini semua masyarakat dituntut untuk selalu waspada dan tetap menjaga kesehatan tubuh mereka, salah satu gejala yang ditimbulkan atau yang dirasakan oleh masyarakat yang terpapar Covid-19 yaitu peningkatan suhu tubuh yang cukup tinggi. Dimana menurut WHO suhu tubuh normal manusia berkisar dari $36,5^{\circ} \mathrm{C}$ $37,5^{\circ} \mathrm{C}$. Suhu tubuh itu sendiri perbedaan antar jumlah panas yang diproduksi oleh proses tubuh dan jumlah panas yang hilang kelingkungan luar, Yang dimana disebabkan oleh beberapa faktor seperti steres maupun pengaruh lingkungan ${ }^{[1]}$.

Dari kemajuannya teknologi pada saat ini muncullah suatu alat yang dapat digunakan dalam mengukur suhu tubuh manusia yaitu alat thermogun, dimana alat ini sangat membantu dan memudahkan masyarakat dalam mengecek suhu tubuh mereka. Tetapi alat ini kurang efektif digunakan pada masa pandemi Covid-19 yang sangat cepat menular pada saat ini, karena alat thermogun yang sering digunakan masih belum otomatis sehingga dalam pengukuruan suhu tubuh membutuhkan orang dalam menjalankan alat tersebut dan mengharuskan seseorang berintraksi secara langsung, hal tersebut akan mengakibatkan penularan Covid-19 secara cepat. Dilihat dari permasalahan diatas teknologi menjadi salah satu alat yang dapat membantu permasalahan tersebut, sehingga dengan membangun alat pengukur suhu tubuh yang memanfaatkan teknologi IOT.

Dengan adanya teknologi Internet Of Things ini diharapkan kondisi suhu tubuh seseorang dapat di cek secara langsung tanpa harus berdekatan yang meminimalisir resiko tertular penyakit Covid 19, sistem ini dipantau melalui aplikasi blynk sehingga data hasil akan dikirimkan secara langsung, dan ketika seseorang melakukan pengecekan suhu tubuh sistem akan menampilkan secara langsung di LCD yang ada pada alat tersebut, dan sistem akan memberikan peringatan dalam bentuk suara apabila suhu tubuh seseorang melebihi batas suhu tubuh yang sudah ditentukan dan memberikan pemberitahuan suhu tubuh seseorang tersebut dalam keadaan normal. Sistem ini dirancang berbasis Internet Of Things agar proses monitoring bisa dilakukan jarak jauh dan resiko 
tertular penyakit akan menjadi lebih kecil. Berdasarkan hal ini penulis ingin membuat sebuah alat pengukur suhu tubuh pintar menggunakan teknologi Internet Of Things dengan menggunakan sensor suhu inframerah MLX90614 sebagai input yang diarahkan ke objek, data yang dibaca berupa data analog yang di olah menggunakan esp8266 dan data tersebut lalu ditampilkan melalui aplikasi blynk yang sudah terhubung secara realtime dan data yang sudah diolah oleh esp8266 juga ditampilkan menggunakan modul LCD dan selain itu juga output yang dihasilkan dalam bentuk suara menggunakan DFPlayer mini.

\section{Tinjauan Pustaka}

\subsection{Peneltian Terkait}

Penelitian ini mengacu pada beberapa konsep penelitian terkait sebelumnya sebagai berikut : -Indra Gunawan, Taufik Akbar, M. Giyandhi Ilham dalam penelitiannya yang berjudul "Prototipe Penerapan Internet Of Things (lot) Pada Monitoring Level Air Tandon Menggunakan Nodemcu Esp8266 Dan Blynk". Dalam kehidupan sehari-hari pemanfaatan tandon atau tangki penyimpaan air belumlah begitu effektif ataupun efisien, karena masih banyak air yang terbuang dalam pengisian air maupun tidak adanya indikator ketinggian air. Oleh karena itu perlu dibuat alat pengontrol ketinggian air pada tandon dimana dalam penelitian ini berbasis IoTs
(Internet of Things). Alat ini menggunakan sensor ultrasonik sebagai pengukur ketinggian air, NodeMCU ESP 8266 sebagai mikrokontroler dan aplikasi Blynk sebagai alat kontrol dan tempat di tampilkannya hasil pengukuran ketinggian air. Alat ini terdiri dari beberapa bagian yang saling terhubung. Mulai dari sensor ultrasonik mengukur ketinggian air lalu di kirim ke mikrokontroler setelah itu di proses, kemudian di kirim ke webserver Blynk sehingga bisa di akses dan ditampilkan oleh aplikasi kontrol. Selain itu juga mikrokontroler terhubung dengan relay yang berfungsi sebagai swich dari pompa air yang bisa di kontrol melalui aplikasi. Hasil penelitian ini yaitu alat dapat memantau stok air dan mengontrol stok air yang kita miliki dengan lebih fleksibel dan efisien walaupun masih belum maximal[2].

-Tanu Keliat dalam penelitiannya yang berjudul "Rancang Bangun Termometer Digital Non Kontak Dengan Output Suara Berbasis Mikrokontroler Atmega 328". Perancangan alat termometer digital dengan output suara ini menggunakan sensor suhu MLX90614 yang komponennya mudah didapat dengan harga terjangkau sebagai pendeteksi suhu badan. Mikrokontroler ATmega328 sebagai pengontrol alat dengan kelebihannya sudah terdapat ADC internal. DF Mini Player sebagai perekam audio dan output berupa suara. Serta LCD untuk displaynya. Range pengukuran termometer ke tubuh manusia sekitar $8 \mathrm{~cm}$. Seperti kita ketahui, 
suhu normal manusia antar 35oC-36oC, dibawah dari suhu tersebut manusia memiliki suhu tubuh rendah yang dapat mengakibatkan hipotermia. Dari hasil pengujian menunjukkan bahwa termometer dengan output suara ini cukup baik, karena dapat mendeteksi suhu hanya dengan rata-rata simpangan 0,450 Celcius. Suara yang dihasilkan juga terdengar lancar tidak patah-patah dan alat bekerja dengan baik[3].

-I Wayan Sukadana, I Made Ade Kristianto, I Wayan Sugara Yasa dalam penelitiannya yang berjudul "Thermometer Bicara Sebagai Upaya Deteksi Dini Covid-19 Berbasis Mikrokontroler ESP8266". Saat ini kita sedang barada dalam kondisi Pandemi Covid-19 atau yang umum dikenal oleh masayarakat luas dengan sebutan Virus Corona. Covid-19 adalah virus yang menyerang system pernafasan hingga menyebabkan kematian. Salah satu anjuran pemerintah bahwa untuk mengantisipasi diri kita terhadap virus ini adalah dengan meningkatkan daya tahan tubuh kita dengan pola hidup sehat. Saat ini di semua area public selalu disediakan Thermogun yang dioperasikan oleh operator untuk pengecekan suhu tubuh. Sistem yang dirancang adalah system yang dapat mendeteksi suhu tubuh seseorang secara langsung tanpa operator yang membawa alat pengukur suhu (Thermogun). Cara kerja Thermometer Bicara ini adalah jika sensor jarak typeHCO4 mendeteksi objek dengan jarak maksimal $5 \mathrm{~cm}$ maka sensor suhu mulai membaca suhu tubuh pengguna dan akan ditampilkan pada LCD dan juga diinformasikan dengan suara. Jika suhu tubuh terdeteksi $37^{\circ} \mathrm{C}$ maka buzzer akan aktif dan speaker akan mengeluarkan suara peringatan. Alat ini menggunakan modul compatible microcontroller ESP8266 sebagai pusat kendali alat dengan sumber tegangan 9 volt DC dan menggunakan box plastic sebagai media Prototype Thermometer.

\subsection{Landasan Teori}

1. Rancang Bangun

Rancang bangun adalah perancanaan, penggambaran dari beberapa elemen yang terpisah kedalam suatu kesatuan yang utuh dan berfungsi.

\section{a. Rancang}

Perancangan atau rancang adalah serangkaian prosedur untuk menterjemahkan hasil analisa dari sebuah sistem ke dalam bahasa pemrograman untuk mendeskripsikan dengan detail bagaimana komponen-komponen sistem di implementasikan. Tujuan dari perancangan ialah untuk memberi gambaran yang jelas lengkap kepada programmer dan ahli yang mengerjakan [5].

b. Bangun

Pembangunan atau bangun sistem adalah kegiatan menciptakan sistem baru maupun memperbaiki sistem yang sudah ada secara menyeluruh. Jadi dapat disimpulkan bahwa 
rancang bangun merupakan penggambaran, dari perencanaan, dan pembuatan sketsa atau pengaturan dari beberapa elemen yang terpisah kedalam satu kesatuan yang utuh dan berfungsi[6].

\section{Alat pengukur}

Pengukuran merupakan membandingkan kuantitas fisik dari objek dan kejadian dunia nyata. Sedangkan alat ukur merupakan alat yang digunakan untuk mengukur bernda atau kejadian tersebut. Fisikawan menggunakan banyak alat untuk melakukan pengukuran. Dimulai dari alat yang sederhana seperti penggaris dan stopwatch sampai ke mikroskop elektron dan pemercepat partikel, bidang ilmu yang mempelajari cara-cara pengukuran dinamakan metrologi[7].

\section{Suhu Tubuh}

Suhu tubuh adalah jumlah panas yang hilang ke lingkungan luar dan dari jumlah panas yang diproduksi oleh tubuh. Suhu mempunyai dua submodalitas yaitu rasa dingin dan rasa panas, Reseptor dingin dan panas ini berfungsi mengindrai rasa panas dan refleks pengaturan suhu tubuh. Reseptor ini dibantu oleh reseptor yang terdapat di dalam system syaraf pusat. Dengan pengukuran waktu reaksi, dapat dinyatakan bahwa kecepatan hantar untuk rasa dingin lebih cepat dibandingkan dengan kecepatan hantaran rasa panas ${ }^{[8]}$.
Suhu tubuh manusia berfluktuasi setiap saat, banyak faktor yang dapat menyebabkan fluktuasi suhu tubuh manusia. Suhu tubuh manusia diatur dengan mekanisme umpan balik (feed back), mekanisme umpan balik ini terjadi bila suhu inti tubuh telah melewati batas toleransi tubuh untuk mempertahankan suhu, yang disebut titik tetap. Titik tetap tubuh dipertahankan agar suhu tubuh inti konstan pada $37^{\circ} \mathrm{C}$. Apabila suhu tubuh meningkat lebih dari titik tetap, rangsangan hipotalamus akan melakukan serangkaian mekanisme untuk mempertahankan suhu dengan cara menurunkan produksi panas dan meningkatkan pengeluaran panas sehingga suhu kembali pada titik tetap[9].

4. Internet Of Things (IOT)

Internet of things merupakan sebuah teknologi yang memanfaatkan jaringan internet secara real time atau terus menerus dengan fitur kontrol jarak jauh. Dimana informasi diambil melalui sensor yang membaca keadaan suatu lingkungan dengan kerja real time dan tanpa adanya intevensi manusia[2].

Pada dasarnya Internet Of Things mengacu kepada sebuah konsep yang bertujuan untuk memperluas manfaat dari konektivitas internet yang tersambung secara terus menerus dengan kemampuan berbagi data, remote control, dan lain sebagainya.

5. Sensor Suhu Non Contact IR (Infra Red) GY$906 \mathrm{MLX} 90614$ 
DOI : 10.29408/jit.v5i1.4615 Link : https://dx.doi.org/10.29408/jit.v5i1.4615

Pemetaan adalah pengelompokkan suatu kumpulan wilayah yang berkaitan dengan MLX90614 adalah sebuah termometer inframerah untuk pengukuran suhu non-kontak. Baik chip detektor thermopile sensitif IR dan ASIC pengkondisi sinyal terintegrasi dalam packing sensor model TO-39 yang sama. Pengkondisi sinyal yang terintegrasi ke dalam MLX90614 itu adalah low noise amplifier, 17-bit ADC dan unit DSP yang kuat sehingga mencapai akurasi dan resolusi tinggi dari termometer.

Secara default dari pabrik, sensor dikalibrasi dengan output SMBus digital yang memberikan akses penuh ke suhu yang diukur dalam kisaran suhu lengkap dengan resolusi $0,02{ }^{\circ} \mathrm{C}$. Pengguna dapat mengkonfigurasi output digital menjadi modulasi lebar pulsa (PWM). Sebagai standar, PWM 10-bit dikonfigurasikan untuk secara terus-menerus mentransmisikan suhu yang diukur dalam kisaran -20 hingga $120^{\circ} \mathrm{C}$, dengan resolusi output $0,14^{\circ} \mathrm{C}$. Menggunakan sensor suhu contactless atau non-contact salah satu solusi untuk membangun sistem sensor yang dapat mengukur suhu tinggi tanpa merusak sistem. Sensor ini dapat merasakan suhu suatu benda tanpa menyentuh benda tersebut[10]. Model sensor MLX90614 dapat dilihat pada gamabar 1.

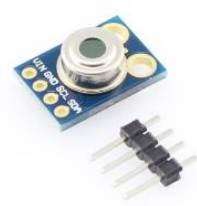

\section{Gambar 1 Sensor MLX90614.}

\section{OLED $12 \mathrm{C} 0.96$ inch}

OLED adalah salah satu media yang digunakan untuk display output untuk modul arduino atau controller lainnya[11]. berukuran $29,28 \times 27,1 \mathrm{~mm}$ dengan resolusi $128 \times 64$ sehingga memiliki kontras pixel yang sangat tajam dan tidak membutuhkan cahaya backlight serta hemat dalam komsumsi daya.

\section{Node MCU}

Node MCU adalah sebuah sebuah kombinasi arsitektur perangkat keras atau platform loT open source berbiaya rendah[12]. menggunakan firmware ESP8266 Wifi SoC dan berbahasa perograman scripting Lua serta support dengan software Arduino IDE.

\section{Arduino IDE}

Arduino IDE adalah sebuah platfrom aplikasi berbasis dekstop yang digunakan sebagai text editor untuk memprogram sebuah perangkat arduino salah satunya NodeMcu ESP8266. Program yang ditulis disebut sketch dengan eksttensi ino[13].

\section{Sensor Ultrasonik HC-SR04}

Sensor ultrasonik adalah sebuah sensor yang berfungsi untuk mengubah besaran fisis (bunyi) menjadi besaran listrik dan sebaliknya. Cara kerja sensor ini didasarkan pada prinsip dari pantulan suatu gelombang suara sehingga dapat dipakai untuk menafsirkan eksistensi (jarak) suatu benda dengan frekuensi tertentu. Disebut sebagai 
DOI : 10.29408/jit.v5i1.4615 Link : https://dx.doi.org/10.29408/jit.v5i1.4615

sensor ultrasonik karena sensor ini menggunakan gelombang ultrasonik (bunyi ultrasonik). Gelombang ultrasonik adalah gelombang bunyi yang mempunyai. frekuensi sangat tinggi yaitu $20.000 \mathrm{~Hz}$. Bunyi ultrasonik tidak dapat di dengar oleh telinga manusia. Bunyi ultrasonik bisa merambat melalui zat padat, cair dan gas. Reflektivitas bunyi ultrasonik di permukaan zat padat hampir sama dengan reflektivitas bunyi ultrasonik di permukaan zat cair. Akan tetapi, gelombang bunyi ultrasonik akan diserap oleh tekstil dan busa. Model sensor ultrasonik dapat dilihat pada gambar 2 .

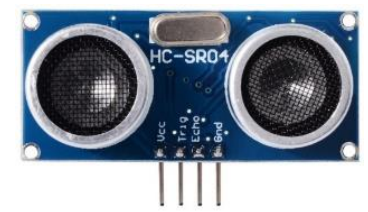

Gambar 2 Sensor ultrasonik HC-SR04

Alat ini memiliki 4 pin, pin Vcc, Gnd, Trigger, dan Echo. Pin Vcc untuk listrik positif dan Gnd untuk ground-nya. Pin Trigger untuk trigger keluarnya sinyal dari sensor dan pin Echo untuk menangkap sinyal pantul dari bendal ${ }^{[14]}$.

\section{DFPlayer mini Mp3}

DFPlayer mini adalah modul mp3 dengan luaran yang telah disederhanakan langsung ke pengeras suara (sepiker). Modul ini dapat digunakan berdiri sendiri dengan baterai, sepikerdan tombol tekan, atau dapat juga dikombinasikan dengan Arduino UNO atau perangkat lainnnya dengan yang memiliki saluran $\mathrm{Rx} / \mathrm{Tx}$. DFPlayer mendukung format audio pada umumnya seperti MP3, WAV,
WMA. Selain itu, juga mendukung TF card dengan sistem file FAT16, FAT32. Melalui port serial yang sederhana, pengguna dapat memainkan musik yang dipilih tanpa perintahperintah rumit untuk melakukannya[15]. Model DFPlayer mini Mp3 dapat dilihat pada gambar 3.

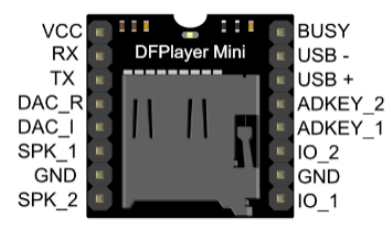

Gambar 3 DFPlayer Mini Mp3

\section{Blynk}

Blynk merupakan aplikasi yang menyediakan layanan server untuk android dan ios yang berguna untuk mengorntrol dan memonitoring perangkat yang berhubungan dengan internet of things seperti ESP8266[15]. Berikut adalah tampilan aplikasi blynk dapat dilihat pada gambar 4.

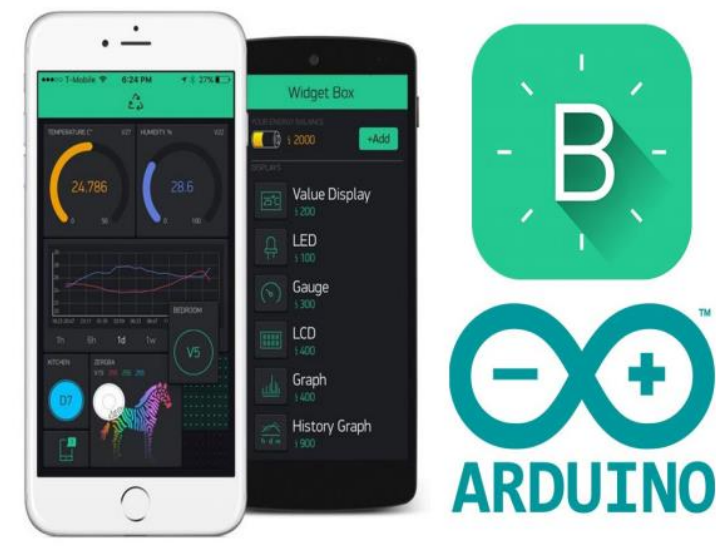

Gambar 4 Blynk 


\section{Metode Penelitian}

1. Flowchart Sistem KerjaProses alur kerja yang di buat pada sistem alat pengukur suhu tubuh akan di jelaskan menggunakan flowchart, alur kerja pada proses sistem yang di bangun diawali dengan inisialisasi portport yang terhubung pada nodemcu dengan perangkat hardware lainnya. Berikut gambar flowchart dapat dilihat pada gambar 5

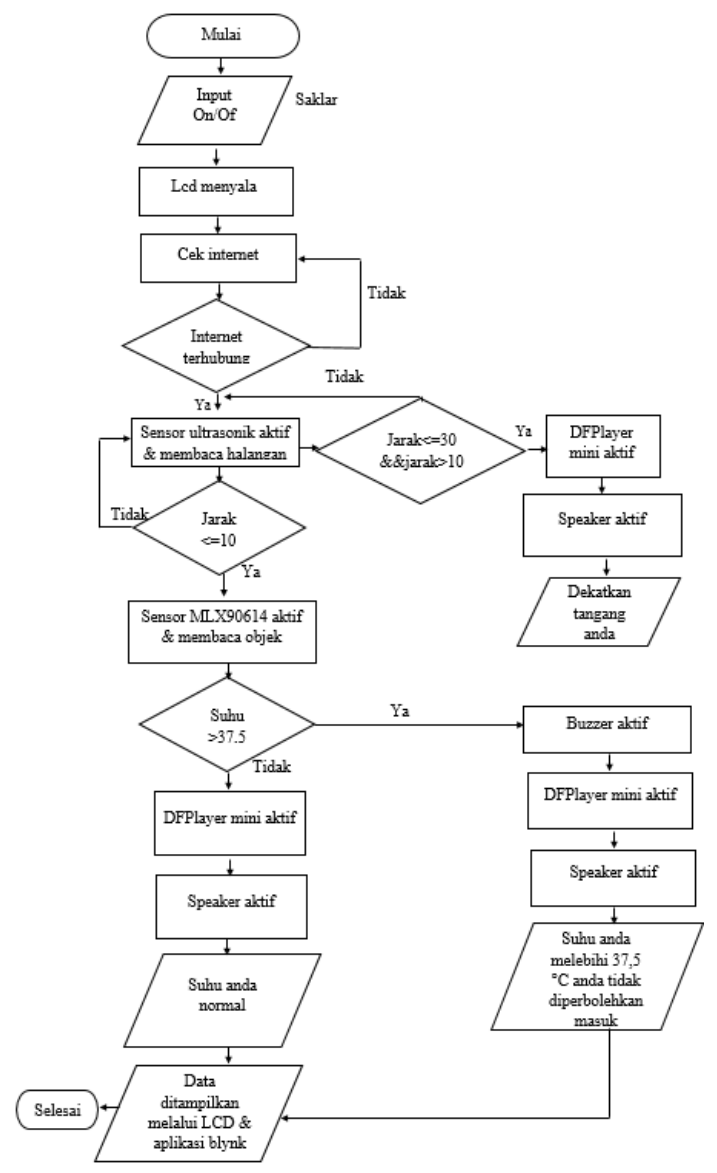

Gambar 5. Flowchart Sisitem Kerja

\section{Rangakaian Alat}

Skema dan desain alat pengukur suhu tubuh pintar dapat dilihat pada Gambar 6.

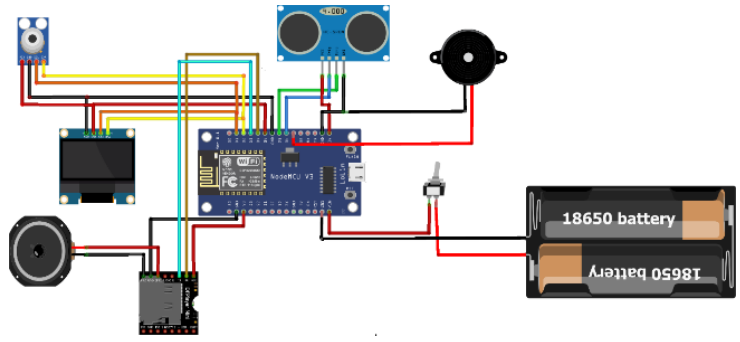

Gambar 6. Rangkaian Alat

\section{Hasil dan Pembahasan}

Berikut ini adalah alat hasil dari penelitian alat pengukur suhu tubuh pintar berbasis internet of things.

\section{Tampilan Alat}

Pada tampilan ini terdapat Bentuk body alat ketika dilihat dari depan terdapat Sensor Mlx90614, Sensor Ultrasonik, LCD OLED, dan Speaker. Dibawah ini adalah tampilan alat dapat dilihat pada gambar 7 .

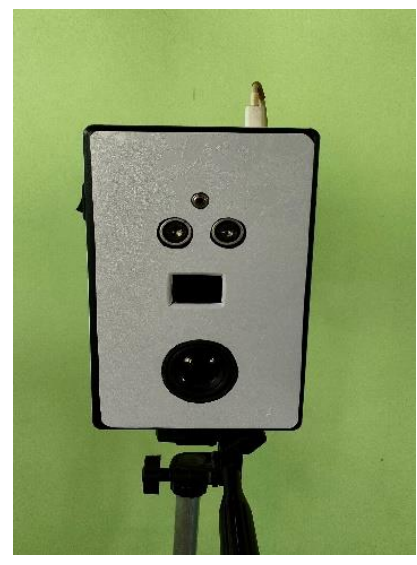

Gambar 7 Tampilan Alat

Dibawah ini adalah tampilan alat ketika digunakan dapat dilihat pada gambar 8 . 


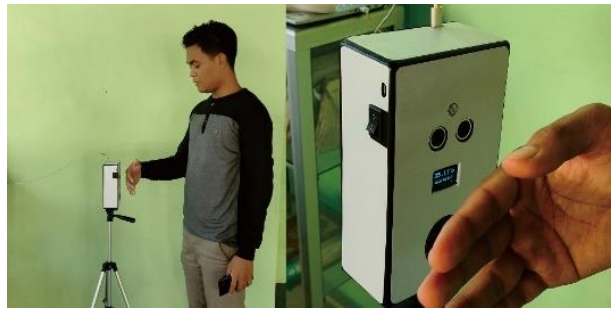

Gambar 8 Tampilan Alat ketika digunakan

2. Tampilan aplikasi

Berikut adalah tampilan antarmuka aplikasi monitoring suhu tubuh. Pada tampilan ini terdapat LCD, gauge, dan superchat akan menampilkan nilai suhu tubuh. Dibawah ini adalah tampilan alat dapat dilihat pada gambar 9 .

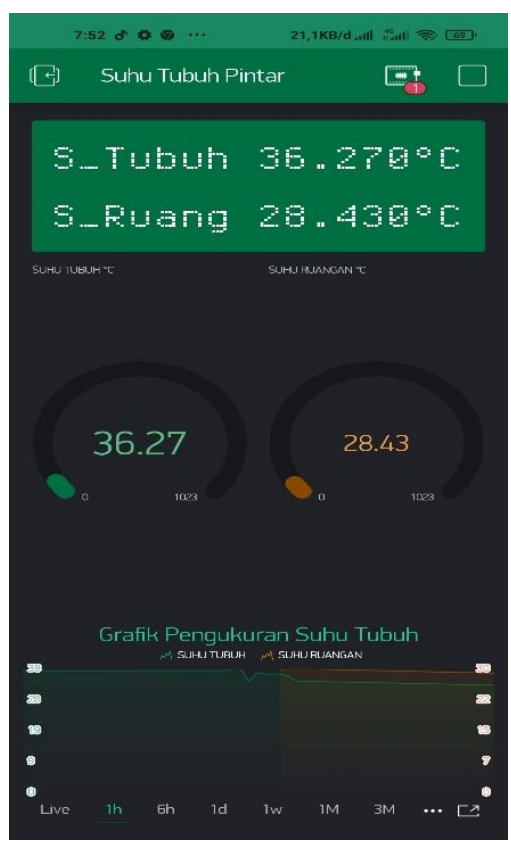

Gambar 9 Tampilan Aplikasi

\section{Pengujian Alat}

Selanjutnya pada tahap ini adalah hasil dari pengujian masing-masing komponen alat. Pengujian ini dilakukan untuk memastikan fungsi dari masing-masing alat berfungsi dengan baik atau tidak. Hasil pengujian
Tahap hasil dari pengujian dilakukan menggunakan lima orang user dengan kondisi tubuh sehat terdiri dari tiga laki-laki dan dua perempuan dengan rentang umur 22-65 tahun untuk melakukan uji coba alat dan untuk membandingkan dengan alat thermogun. Tabel hasil pengujian dapat dilihat pada tabel 2 .

Tabel 2 Hasil Pengujian

\begin{tabular}{|c|c|c|c|c|c|}
\hline No. & User & $\begin{array}{l}\text { Hasil } \\
\text { Alat }\end{array}$ & $\begin{array}{c}\text { Thermogu } \\
\mathrm{n}(\mathrm{SNI})\end{array}$ & Error & Waktu \\
\hline 1. & $\begin{array}{c}\text { User } \\
1\end{array}$ & $36,8^{\circ} \mathrm{C}$ & $36,5^{\circ} \mathrm{C}$ & $\begin{array}{c}0,003 \\
{ }^{\circ} \mathrm{C}\end{array}$ & 3 detik \\
\hline 2. & $\begin{array}{c}\text { User } \\
2\end{array}$ & $37,1^{\circ} \mathrm{C}$ & $37,0^{\circ} \mathrm{C}$ & $\begin{array}{c}0,002 \\
{ }^{\circ} \mathrm{C}\end{array}$ & 3 detik \\
\hline 3. & $\begin{array}{c}\text { User } \\
3\end{array}$ & $35,0^{\circ} \mathrm{C}$ & $35,7^{\circ} \mathrm{C}$ & $\begin{array}{c}0,019 \\
{ }^{\circ} \mathrm{C}\end{array}$ & 3 detik \\
\hline 4. & $\begin{array}{c}\text { User } \\
4\end{array}$ & $35,2^{\circ} \mathrm{C}$ & $35,7^{\circ} \mathrm{C}$ & $\begin{array}{c}0,014 \\
{ }^{\circ} \mathrm{C} \\
\end{array}$ & 3 detik \\
\hline 5. & $\begin{array}{c}\text { User } \\
5\end{array}$ & $36,3^{\circ} \mathrm{C}$ & $36,7^{\circ} \mathrm{C}$ & $\begin{array}{c}0,010 \\
{ }^{\circ} \mathrm{C}\end{array}$ & 3 detik \\
\hline \multicolumn{2}{|c|}{ Rata-rata } & 36,08 & 36,32 & $\begin{array}{c}0,0096 \\
{ }^{\circ} \mathrm{C}\end{array}$ & \\
\hline
\end{tabular}

Pengolahan data :

Rumus nilai error dari alat ukur yang dibuat dengan alat Thermogun

$$
\text { Error }=\frac{\text { Thermogun }- \text { alat }}{\text { Thermogun }} \times 100 \%
$$

Sampel :

$$
\begin{aligned}
\text { Error } & =\frac{36,5^{\circ} \mathrm{C}-36,8^{\circ} \mathrm{C}}{36,5^{\circ} \mathrm{C}} \times 100 \% \\
& =0,8^{\circ} \mathrm{C}
\end{aligned}
$$

Rumus nilai akurasi dari alat ukur yang dibuat dengan alat Thermogun

$$
X=\left|\frac{x_{\text {Suhu tubuh pintar }}}{x_{\text {thermogun }}}\right| x 100 \%
$$

$X=$ Persentase perbandingan dari kedua alat tersebut

$X_{\text {Suhu tubuh pintar }}=$ Rata-rata dari alat yang sudah dibuat 
$X_{\text {thermogun }}=$ Rata-rata dari alat SNI

$$
\begin{aligned}
X & =\frac{36,08{ }^{\circ} \mathrm{C}}{36,32{ }^{\circ} \mathrm{C}} \times 100 \% \\
& =99,33 \%
\end{aligned}
$$

Dari tabel dan pengolahan data diatas perbandingan hasil pembacaan suhu tubuh menggunakan alat yang telah dibuat menggunakan sensor MLX906 dengan Thermogun yang ada dipasaran. Hasil yang didapat dari pembacaan tidak berbeda jauh. Pengukuran menggunakan alat yang telah dibuat dengan Thermogun memiliki rata-rata error yakni $0,8 \%$.

\section{Kesimpulan}

Kesimpulan berdasarkan data hasil penelitian dan pembahasan yang telah diuraikan diatas, maka dapat diambil kesimpulan :

1. Pengukuran suhu tubuh yang paling efektif pada alat pengukur suhu tubuh berkisar pada jarak 5-10 cm dengan objek, baik itu pada tangan atau kening.

2. Nilai hasil pembacaan suhu tubuh yang ditampilkan melalui LCD OLED, aplikasi blynk dan pemberitahuan dalam bentuk suara sudah berjalan dengan baik sesuai yang diharapkan.

3. Aplikasi blynk menerima data sensor dan menampilkan data sensor dengan baik selama aplikasi terkoneksi dengan jaringan internet.

4. Alat tetap dapat digunakan apabila koneksi internet terputus dan menampilkan nilai pembacaan suhu tubuh hanya melaluli LCD OLED.

5. Pemberitahuan dalam bentuk suara dan alarm ketika sistem mendeteksi suhu berlebih.

\section{Daftar Pustaka}

[1] M. O. Sibuea, "Pengukuran Suhu Dengan Sensor Suhu Inframerah Mlx90614 Berbasis Arduino," Univ. Sanata Dharma, vol. 1, pp. 1-70, 2018.

[2] I. Gunawan, T. Akbar, and M. Giyandhi Ilham, "Prototipe Penerapan Internet Of Things (lot) Pada Monitoring Level Air Tandon Menggunakan Nodemcu Esp8266 Dan Blynk," Infotek J. Inform. dan Teknol., vol. 3, no. 1, pp. 1-7, 2020, doi: 10.29408/jit.v3i1.1789.

[3] L. Hikmah, R. A. Rochmanto, and S. Indriyanto, "Implementasi Termometer Non Kontak Digital Berbasis Internet Of Things untuk Mencegah Penyebaran Covid-19," J. EECCIS, vol. 14, no. 3, pp. 108-114, 2020.

[4] T. Keliat, "rancang bangun termometer digital non kontak dengan output suara berbasis mikrokontroler atmega 328," p. 6 , 2021.

[5] U. B. Helmy Yudhistira Putra1, "Rancang Bangun Pengukur Suhu Tubuh 
Menggunakan Multi Sensor," vol. 1, no. 10, pp. 543-549, 2021.

[6] I. W. Sukadana, I. M. A. Kristianto, and I. W. S. Yasa, "Thermometer Bicara Sebagai Upaya Deteksi Dini Covid-19 Berbasis Mikrokontroler ESP8266," vol. 2, no. 1, pp. 1-11, 2021.

[7] D. A. A. Novitasari, D. Triyanto, and I. Nirmala, "Rancang Bangun Sistem Monitoring pada Limbah Cair Industri Berbasis Mikrokontroler dengan Antarmuka Website," Coding J. Komput. dan Apl. Untan, vol. 06, no. 03, pp. 43-53, 2018.

[8] Kurniawan, "rancang bangun knowledge management system berbasis web pada madrasah mualimin al-islamiyah uteran geger madiun," vol. 87, no. 1,2 , pp. 149 200, 2017.

[9] F. Sugara, "Rancang Bangun Alat Penurun Suhu Tubuh," vol. 13, no. 2, pp. 97-103, 2017.

[10] K. Anisa, "Efektifitas Kompres Hangat Untuk Menurunkan Suhu Tubuh Pada an.D Dengan Hipertermia," J. IIm. IImu
Kesehat. Wawasan Kesehat., vol. 5, no. 2, pp. 122-127, 2019, doi: 10.33485/jiikwk.v5i2.112.

[11] P. I. Jatmiko, A. J. Taufiq, and W. Dwiono, "Alat Pengukur Suhu Badan Dan Detak Jantung Portable," J. Ris. Rekayasa Elektro, vol. 1, no. 1, pp. 25-30, 2019, doi: 10.30595/jrre.v1i1.4926.

[12] S. R. Sokku and S. F. Harun, "Deteksi Sapi Sehat Berdasarkan Suhu Tubuh Berbasis Sensor MLX90614 dan Mikrokontroller," pp. 613-617, 2019.

[13] N. A. Firdausi, protipe alat monitoring detak jantung portabel menggunakan arduino promini dana bluetooth berbasis android. 2018.

[14] T. Akbar and I. Gunawan, "Prototype Sistem Monitoring Infus Berbasis IoT (Internet of Things)," Edumatic J. Pendidik. Inform., vol. 4, no. 2, pp. 155163,2020,doi:10.29408/edumatic.v4i2.268 6.

[15] H. Santoso, "Panduan Praktis Arduino untuk Pemula," 2016, p. 115. 